\title{
A PERSONAGEM FRACASSADA NO ROMANCE DE 30 EM ALGUMAS NARRATIVAS DO DESLOCAMENTO
}

\author{
Pedro Barbosa Rudge Furtado (Unesp)
}

Resumo: O nosso artigo intenciona analisar a relação dialética do deslocamento espaciotemporal em quatro narrativas do decênio de 30: $O$ anjo, de Jorge de Lima, Maleita, de Lúcio Cardoso, Angústia, de Graciliano Ramos, e $O$ amanuense Belmiro, de Cyro dos Anjos, lançadas, respectivamente, em 1933, 1934, 1936 e 1937. O nosso fito é mostrar como a ocorrência dos movimentos espaciotemporais concorrem para o realce da representação do sentimento de fracasso. 0 aparecimento da personagem fracassada foi notado, primeiramente, por Mário de Andrade (2002) em "Elegia de abril", publicado em 1941. Cabe indicar que, mesmo no subtexto das narrativas, há tensões animadas na relação com o outro como ser - a alteridade - e o outro como espaço-tempo, cada um carregando os seus correspondentes valores. Por meio de estudos de Tim Cresswell (2006), sobre a espacialidade e suas representações, de Sérgio Miceli (2011) e de Antonio Candido (1989) sobre o sentimento de negatividade presente nos romances de 30, de Luís Bueno (2015), versando sobre as narrativas do período em questão, e textos críticos acerca delas, procuramos demonstrar como a sua forma/conteúdo oferece pertinentes discussões a respeito do deslocamento interligado à lógica do poder e da noção de não-pertencimento das personagens derrotadas.

Palavras-chave: Representação do deslocamento; Personagem fracassada; Espaço; Tempo; Romance de 30.

Abstract: This paper aims to analyze the dialectical relation regarding the spatial and temporal dislocation on four narratives of Brazilians thirties: $O$ anjo, by Jorge de Lima, Maleita, by Lucio Cardoso, Angústia, by Graciliano Ramos, and $O$ amanuense Belmiro, by Cyro dos Anjos, that were released in 1933, 1934, 1936 and 1937, respectively. Our goal is to show how the occurrence of spatial and temporal movements contribute to the enhancement of representation regarding the characters' feelings of failure. The emergence of the failed characters is pointed out, firstly, by Mário de Andrade (2002) on "Elegia de Abril", published in 1941. 
It is possible to indicate that, even in the subtext of narratives, there are tensions animated by the relation with the other as a character or as space and time, each of them carrying the respective values. Using Tim Cresswell's (2006) book about spatiality and its representation, Sérgio Miceli's (2001) and Antonio Candido's (1989) papers concerning the feeling of negativity presented in the thirties novels, Luís Bueno's (2015) work treating of Brazilians thirties novels, and critical papers related to these narratives, it is aimed to demonstrate how the form and content of these novels offer pertinent issues linking the displacement to the logics of power and the feeling of non-belonging on the defeated characters.

Keywords: Displacement representation; Failed character; Space; Time; Thirties novel.

\section{INTRODUÇÃO}

Tim Cresswell (2006, p.26-7), discutindo a metafísica sedentária de alguns indivíduos na modernidade, assinala que o deslocamento, no caso deles, pode gerar impactos severos no que tange, principalmente, ao caráter identitário do sujeito. Pensar num espaço, então, vinculado intrinsecamente à formação da pessoa, territorializa as práticas culturais e suas variantes linguísticas e sociais. Logo, a mudança macro do homem - de uma região a outra - produz uma desarticulação entre os diversos princípios do novo em contraste com os diversos valores do velho espaço. Essa dinâmica é, também, inevitavelmente temporal, uma vez que a passagem do tempo exterior não é interrompida.

No terreno artístico-literário, o espaço-tempo é uma força motivadora de representação das tensões de personagens da narrativa. Se o tempo interior sobressai, grosso modo, 
em vários romances do zeitgeist moderno, especialmente com a complicação do ser-de-papel-advinda, entre outros fatores, dos estudos psicanalíticos, ligados à noção de fracionamento da pessoa - nos primeiros decênios do século $X X$, o tempo exterior (incontrolável) e o espaço (incontornável) conjugamse no grave sentimento de mal-estar visto em várias personagens dessa época.

No caso do romance de 30, a gênese da dinâmica espacial apresenta diversas facetas: a da necessidade de sobrevivência, como em Vidas secas, de Graciliano Ramos; a da tentativa de humanização, mesmo descompassada e antiteticamente violenta, de Lula sobre as classes populares em Calunga, de Jorge de Lima; a da promessa de dignificação do homem e de sua família, por meio do trabalho nos grandes centros, como em Navios iluminados, de Ranulfo Prata, etc. Em todos eles, há algo em comum: o sentimento de não-pertencimento encetado pelas mudanças. Tanto esses romances, como os analisados nesse artigo e em outros daquele decênio, são caracterizados pelo alto grau de embates que os movimentos espaciais animam, sendo eles o ponto fulcral no que tem a ver com os conflitos, ontológicos e/ou histórico-sociais, trazidas à tona. Chamamos essas composições de narrativas do deslocamento. 
Investigamos, sucintamente, os efeitos dos deslocamentos, nas personagens fracassadas, primeiramente em Maleita, de Lúcio Cardoso. Embora ligado aos valores cristãos da época, o artista mineiro concebe, tanto em Maleita quanto em Salgueiro (1935) romances lidos como sociais, apesar do seu latente tom conservador. As mudanças espaciotemporais são investigadas, posteriormente, em Angústia, de Graciliano Ramos, autor que imbrica, de modo notável, modulações sociais e psicológicas. O terceiro romance é $O$ amanuense Belmiro, de Cyro dos Anjos; composto a partir da forma diário, ele nubla as tensões histórico-sociais por meio do lirismo e da ironia.

Lançadas, respectivamente, em 1934, 1936 e 1937, essas obras fazem uso do narrador em primeira pessoa, o que, segundo Luís Bueno (2015), proporciona dois efeitos relevantes:

Primeiro, o de conferir veracidade maior ao documento, já que assim ele aparece construído como depoimento de quem viveu aquele fracasso; segundo, o de sublinhar o caráter definitivo das derrotas narradas, já que para ninguém o impasse pode ser tão profundo, ou mais sem saída, do que para aquele a quem não é dada uma perspectiva mais ampla ou distanciada do problema. (p.78)

Se o efeito aporético da vida é mais enfatizado mediante a narração em primeira pessoa, examinamos, de modo mais 
detido, como é edificada a constante Queda de Herói em $O$ anjo, de Jorge de Lima. Narrado em terceira pessoa, a partir de capítulos curtos, fragmentados e um tanto desconexos, a obra é pautada numa severa cosmovisão católica. Veremos como o mal-estar transgressivo, provocado pelo corruptivo Rio de Janeiro, está fortemente ligado a processos históricosociais, salientados pelas viagens do protagonista.

\section{FIGURAÇÃO DO FRACASSO NAS NARRATIVAS DO DESLOCAMENTO}

Mário de Andrade (2002) observa, em "Elegia de Abril", que há a proliferação na literatura dos anos 30 de tramas que lidam com a trajetória do fracasso de algumas personagens. Segundo ele, a representação da derrota não deriva, como nas obras-primas da literatura mundial, de duas forças em luta, em que há a figuração de personagens dotadas de "ideias, de ambições enormes, de forças morais, intelectuais, físicas [...]", mas, ao contrário, o herói da nossa ficção é

a descrição do ser sem força nenhuma, do indivíduo desfibrado, incompetente para viver, e que não consegue opor elemento pessoal nenhum, nenhum traço de caráter, nenhum músculo como nenhum ideal, contra a vida ambiente. Antes, se entrega à sua conformista insolubilidade. (ANDRADE, 2002, p.212-213)

O sociólogo Sérgio Miceli (2001) parece dialogar com as assertivas de Mário de Andrade. Entretanto, diferentemente 
do intelectual paulista, Miceli busca explicar os motivos pelos quais o tema da decadência é amiúde explorado pelos nossos romancistas por meio de aproximações entre a biografia familiar de alguns escritores, o conteúdo de sua prosa e as dinâmicas culturais da época. Há de se destacar que Miceli não intenciona dedicar-se a uma hermenêutica imanente do texto literário; ele procura, sim, localizar nessas obras sintomas do declínio social de que

se nutriam os quadros governamentais depois de 1930, quando o abalo das estruturas tradicionais e o predomínio do ritmo urbano suscitam novos tipos de clientela, patronato, dependência e concepção de trabalho. (CANDIDO, 2001, p.75)

Miceli aprofundou os estudos sobre a grave polarização ideológica que tomou conta de boa parte do decênio em questão e se alastrou, mesmo que residualmente, nas próximas décadas. Sabemos, principalmente depois da meticulosa análise intratextual da prosa de então em Uma história do romance de 30, de Luís Bueno (2015), que era requerida a composição de obras que versassem sobre o chão social, com caráter de documento (palavra assaz usada a fim de caracterizar o romance regionalista nordestino) dos intelectuais de esquerda; dos de direita, ao contrário, o foco deveria ser estabelecido nas tensões ontológicas, 
apartando-se dos conflitos socio-históricos. Felizmente, alguns romancistas conseguiram escapar dessa equação domesticadora, como Dyonélio Machado, Graciliano Ramos, Cyro dos Anjos, João Alphonsus, Marques Rebelo, entre alguns poucos outros.

O mais intrigante da argumentação de Sérgio Miceli é a sinalização de que tanto os escritores intimistas quanto os de cunho social, e os que imbricavam essas duas formas simbólicas, desenvolviam, de algum modo, o tema da decadência. No quadro 5 de Intelectuais e classe dirigente no Brasil chamado "Origem social, trunfos, handicaps e carreira", o sociólogo sintetiza, com o afã de associá-las, as histórias de vida e as origens sociais dos "cronistas da casa 'assassinada"” (MICELI, 2001, p.158), modo pelo qual ele batiza os escritores que figuravam a derrocada das personagens. Os autores arrolados no quadro são: Cyro dos Anjos, Cornélio Penna, Marques Rebelo, Érico Veríssimo, Graciliano Ramos, Lúcio Cardoso, Jorge Amado, José Geraldo Vieira, José Lins do Rego, Octavio de Faria, Orígenes Lessa e Rachel de Queiroz.

Vê-se que o quadro consagra uma mirada panorâmica em termos de composição literária - há enorme diferença entre a modulação linguística de José Geraldo Vieira e Rachel de Queiróz, por exemplo - de localização geográfica - desde 
o centro com escritores paulistas e cariocas até a periferia econômica do Brasil com romancistas do Sul e do Nordeste - e de posição política - Octavio de Faria, claramente de direita, Jorge Amado, claramente de esquerda, por exemplo. De acordo com Miceli (2001), todos esses artistas sofreram, grosso modo, com a perda do poder econômico e simbólico dos quais eles participavam, sendo os únicos aptos para representar a ruína:

não há chance de obter nenhuma garantia de objetividade acerca do mundo social a menos que os produtores dessa reconstrução simbólica - sejam eles artistas, escritores ou cientistas - tenham vivido a experiência dramática de serem desalojados da posição social que o seus vinham ocupando, a única maneira de se familiarizarem com outros pontos de vista sem que por isso consigam se desvencilhar do setor da classe dirigente de que são originários. (2001, p.163)

O tom assertivo com que Miceli elabora a sua argumentação nos causa certo desconforto, levando-nos, ainda, ao inevitável cotejo entre vida e figuração literária, entre sinais ficcionais e reais, que muitas vezes criam leituras desajuizadas das prosas em si. De qualquer modo, o painel traçado pelo sociólogo nos dá a dimensão do que seria a alastrada perspectiva negativa sobre o presente, de que Antonio Candido (1989) trata com argúcia em "Literatura e subdesenvolvimento". 
Por meio das reflexões de Mário Vieira de Mello em Desenvolvimento e cultura: o problema do estetismo no Brasil, Candido (1989, p.169) comenta as noções de "país novo", que eram atribuídas às nações da América Latina, onde havia a "possibilidade de progressos futuros", e "país subdesenvolvido". Essa última ideia vem à tona a partir da tomada de consciência, por parte de alguns intelectuais, de que, em contraste com a esperança de crescimento, destacava-se, ao contrário, a pobreza, a atrofia de um País. Há a percepção de que as revoluções dos anos de 30 não fraturaram totalmente o modus operandi das nossas estruturas de poder:

o tenentismo liberal e a política getuliana só em parte aboliram o velho mundo, pois compuseram-se aos poucos oligarquias regionais, rebatizando antigas estruturas partidárias, embora acenassem com lemas patrióticos ou populares para o crescente operariado e as crescentes classes médias. (BOSI, 2006, p.410)

Entretanto, Antonio Candido (1989, p.171-2) afirma que a consciência generalizada do subdesenvolvimento vem à tona após a Segunda Guerra Mundial; porém, o romance regionalista de 30 "adquiriu uma força desmistificadora que precede a tomada de consciência dos economistas e políticos". 
Assim, a representação dos deslocamentos espaciotemporais particulares, nessa ficção, está em aderência com a tomada de consciência de nosso atraso político, econômico e cultural. A reunião desses motivos parece bastante relevante na criação de figurações das rupturas identitárias sentidas pelas personagens inseridas em choques valorativos, contidos na outra espacialidade e nos outros seres-de-papel.

\section{A FIGURAÇÃO DO DESLOCAMENTO EM QUATRO CRONISTAS DA CASA ASSASSINADA}

\subsection{A BRUTALIDADE DO CIVILIZADOR EM MALEITA, DE LÚCIO CARDOSO}

O primeiro livro de que trataremos é Maleita, de Lúcio Cardoso, publicado em 1934 e bastante aliado aos valores conservadores de então. O romance de estreia do escritor mineiro é marcado por uma tentativa de representação histórica, altamente estilizada, do desenvolvimento da cidade de Pirapora. A narrativa se passa no ano de 1893, quando o narrador-protagonista - que então morava em Curvelo, situado num território próspero - é enviado por uma companhia comercial com o intuito de desenvolver Pirapora. O embate chave da narrativa se dá entre a civilização e a barbárie, entre a violência do colonizador e a do colonizado.

Essas tensões são construídas a partir da mirada do homem instruído sobre as classes populares, o que suscita 
diversos embaraços quando analisamos o romance a partir de uma visada ideológica. O protagonista não é apto a se irmanar daquele povo considerado por ele bestial; assim, os fatos são narrados do ponto de vista de seu choque perante ao que ele não consegue, e não tenta, de maneira nenhuma, entender.

São vários os trechos em que ações da alteridade são destituídas de sensatez pelos olhos do narrador. Relatando os casos de violência de Pirapora, por exemplo, ele assevera que esses atos brutais "denunciava[m] o sangue abominável daquele gentio, acostumado, como às feras, somente à lei da natureza" (CARDOSO, 2005, p.87).

Evidenciam-se, de acordo com a citação anterior e a leitura do livro, os contundentes tons naturalistas trazidos à tona pela prosa, e resgatados, também, pelo referencial histórico em que a narrativa se passa. O ano de 1893 sustenta a perspectiva despótica do protagonista sobre as outras personagens. Os viventes de Pirapora, de acordo com o meio em que vivem, só podem ser consumidos pela selvageria ao redor. O protagonista tem a incumbência, nesse cenário, de iluminar, com a razão, aquele povo. Assim, os castigos os quais a personagem principal institui sobre os negros da região - com chicotes, remetendo-nos à escravidão - são relatados com ares de dever civilizatório. 
Grande parte desses embates apresentam como forçamotriz o deslocamento do protagonista, que narra e detém o ponto de vista da narrativa. O modus vivendi dos seres que o rodeiam causa estranheza no forasteiro, enquanto nas outras personagens, o deslocamento do civilizador (e deles próprios, auxiliando na construção da cidade) significa um processo de aculturação a partir da tentativa de modernização - violenta - dos modos de trabalho e a domesticação dos seus jeitos de ser. O narrador, impondo-se incessantemente sobre os outros, torna-se o seu adversário:

Mandei Bento chamar os outros trabalhadores. Percebi a provocação que encerrava aquela orgia mantida na estrada. Reunidos, marchamos cautelosamente.

Felão já veio?

não veio não

por que é que não veio

não sei não...

Não compreendi de momento porque cantavam aquilo. Pareceu-me estranha a toada, diferente das outras que estava acostumado a ouvir. Bento tocou-me e disse: - O patrão apercebe? Felão é vossemecê... Felão, espécie de figura de lenda, perverso e sanguinário... Recordava um facínora, Félix, que por ser muito grande ficara chamado Felão. Os homens entoavam em coro. (CARDOSO, 2005, p.92) 
Se a cosmovisão representada no livro é conservadora, a contrapelo, ela coloca a nu a brutalidade do invasor civilizado contra o invadido visto como bárbaro, a partir, principalmente, das intromissões da voz das classes populares nos diálogos com o narrador-protagonista. Fatalmente, ele é consumido pela maleita, único modo de aproximá-lo dos outros viventes.

\subsection{OS TEMPOS DA INADEQUAÇÃo EM ANGÚSTIA, DE GRACILIANO RAMOS}

Em Angústia, terceiro romance de Graciliano Ramos, autor declaradamente de esquerda, o deslocamento espaciotemporal sofrido pela personagem cria, in extremis, o sentimento de não-pertencimento do ser em face dos valores vigentes numa Maceió em processo de urbanização e de capitalismo incipiente. Essa estrutura social está em contraponto com as micronarrativas do romance, que são os flashbacks rememorativos do passado infantil de Luís da Silva, em que a família do narrador-personagem, mesmo com a falência do meio de produção escravocrata, ainda detinha certo prestígio e poder na região. Com a total destruição da fazenda, Luís deve migrar para a capital do Estado.

Vejamos os movimentos temporais do romance, que levantam as variações entre estados da personagem no que tem a ver com a sensação de pertencimento 
e não-pertencimento (FURTADO, 2017, p.98): a narrativa é iniciada com o protagonista em estado de aturdimento, ainda tentando recuperar-se dos eventos ocorridos, principalmente o assassinato de Julião Tavares, cometido por ele, e sua consequente prisão. Enquanto é verificada essa grave perturbação - ocasionada, também, pela sensação de inadequação à ordem vigente - ele é motivado a refugiar-se na infância por meio da rememoração do passado remoto, em que se irmanava - ou supunha tal irmanação - na outra ordem.

À medida que relata as memórias e reaviva como travou conhecimento com Marina, planejando o seu casamento, ou seja, enquanto ainda se sente adequado à ordem urbana, as micronarrativas não vêm à tona. Após perder Marina para o endinheirado Julião Tavares, irrompe, mais uma vez, o sentimento de desajuste em relação aos valores da capital; dessa forma, retomam-se as lembranças do passado rural e remoto. A narrativa é construída, então, no contínuo contraponto entre os tempos da enunciação e a cadeia valorativa manifestada por meio deles.

Assim, o protagonista, por julgar pertencer ao espaçotempo de outrora - ao campo e aos valores de então não é apto a se congraçar com absolutamente ninguém no 
espaço-tempo de agora - a cidade com os valores atuais em que se vê no ápice da frustração, tornando-se menos poroso às diferenças do presente e do passado próximo. 0 caminhar na região mais povoada da cidade, por exemplo, é uma tribulação para Luís:

Quanto mais me vejo rodeado mais me isolo e entristeço. Quero recolher-me, afastar-me daqueles estranhos que não compreendo, ouvir o Currupaco, ler, escrever. A multidão é hostil e terrível. Raramente percebo qualquer coisa que se relacione comigo: um rosto bilioso e faminto de trabalhador sem emprego, um cochicho de gente nova que deseja ir para a cama, um choro de criança perdida. (RAMOS, 2011, p.137)

No fim e ao cabo, os conflitos íntimos e insolúveis de Luís da Silva levam-no, progressivamente, à loucura, que é mimetizada no monólogo interior final do romance, em que ele mistura tantos os fantasmas de sua infância, quanto os de sua fase adulta, representando uma dramática crise identitária, numa confusão de princípios. A falta de adequação de Luís da Silva indica o desajustamento provindo de forças históricas motivadas pelo deslocamento espaciotemporal - em tensão, absorvidas pela mente irrequieta do protagonista.

\subsection{DESLOCAMENTO COMO SUBTEXTO HISTÓRICO-SOCIAL EM $O$ aMANUENSE BELMIRO, DE CYRo dos ANJOS}

Como em Angústia, a crise identitária é figurada - porém em outros moldes - em $O$ amanuense Belmiro, romance 
que imbrica intimismo e tensão social. Homologamente ou não - uma vez que o romance é trabalhado a partir de uma intensa carga estética e o ser-de-papel produzido por meio de diversos recursos narrativos - ao estado de espírito de Cyro dos Anjos, que se mostrava um tanto confuso diante da intensa polarização ideológica, é construída uma personagem altamente complexa e de consciência vigilante. Ela é, no entanto, pouco assertiva - confessando as suas dúvidas - flutuando em dimensões espaciotemporais e políticas: campo, cidade, esquerda, direita, transcendência, materialidade etc.

Vários indícios concebem o "detalhe social" (SCHWARZ, 2008 , p.17) do romance de Cyro dos Anjos. Assinalemos dois que se combinam com o intuito de evidenciar os motivos do desajuste interior de Belmiro, que se esforça arduamente na sua harmonização: o trato com o outro e o desarranjo na relação que ele mantém com o presente.

O fito de Belmiro é "reviver o pequeno mundo caraibano" (ANJOS, 2006, p.26), mas ele é invadido, continuamente, pelas tensões do agora. Não é, ainda, um agora qualquer: é o ano de 1935, em que houve a formação e a queda da Aliança Nacional Libertadora, que registrou, ainda, o final da intentona comunista. Evadir-se do presente, então, é fugir dos seus embates acalorados. 
O impulso do protagonista de se fixar no passado é um engodo. Em suas notas, mesmo afirmando que entrou "numa fase da vida em que o espírito abre mão de suas conquistas, e o homem procura a infância, numa comovente pesquisa das remotas origens do ser" (ANJOS, 2006, p.33), ele não se atém apenas ao processo rememorativo de maior alcance temporal; aliás, a narrativa é preenchida mais por elementos do cotidiano do que do passado da fazenda; ou melhor, a infância na fazenda, "seu quinhão de vida rural, é simplesmente apagada da narrativa [...]" (BUENO, 2015, p.555).

No entanto, Belmiro alude brevemente ao distante período em que a sua família detinha aquelas terras. Segundo o protagonista, foi com o seu pai "que começou o desvio da linhagem rural" (ANJOS, 2006, p.22), pois ele também não se adequava à fazenda. Há, assim, um certo desconforto do narrador quanto ao seu caminho de vida; sente-se como "um fruto chocho do ramo vigoroso dos Borbas, que teve seu brilho rural" (p.21). Decidindo não se tornar agrônomo, como a família o queria, testemunhou o ruir das terras dos Borbas: "Lá estava a fazenda, grande, poderosa como um estabelecimento público, com suas lavouras à espera de cuidados moços" (p.21). 
Muito afastado da profissão que lhe fora aconselhada pela família, o protagonista torna-se um amanuense, residindo na primeira capital planejada do Brasil, Belo Horizonte. Os relatos do seu cotidiano como funcionário público, numa enunciação próxima do agora por meio do suporte do diário, são confrontados pelas lembranças do modo de vida na saudosa Vila Caraíbas.

A pulverização dos preceitos do presente urbano de Belmiro situa-se nas conflituosas diferentes visões de mundo dos seus amigos. Logo no primeiro capítulo, o narrador conta a cena que sucede numa mesa de bar na véspera do Natal. Lá estão Belmiro, Florêncio - "o homem sem abismos" e "linear" (ANJOS, 2006, p.115) - Silviano - filósofo defensor dos problemas atemporais - e Redelvim - revolucionário de esquerda preocupado com as mazelas sociais. Angustiados por chegarem à conclusão, "ali pelo oitavo chope", de que "todos os problemas eram insolúveis", Florêncio sugere um nono chope, "argumentando que o outro copo talvez trouxesse uma solução geral" (ANJOS, 2006, p.15). As discussões, no entanto, continuam. As divergências agravamse na fala de Silviano e na seguinte reação de Redelvim:

- A solução é a conduta católica, afirmou o amigo Silviano, meio vago, como que atendendo a uma ordem interior de reflexões, que não era bem a de nossa conversação. 
Redelvim convidou-me, com um olhar malicioso, a prestar atenção ao filósofo.

- Hein? Indaguei, voltando-me para este.

- A conduta católica, repetiu. Isto é, fugir da vida, no que ela tem de excitante [...]. (ANJOS, 2006, p.15)

Como bem assinala Luís Bueno (2015, p.557), Belmiro é obstinado a sempre evitar, ou apaziguar, as crises entre os companheiros, o que é atestado logo no parágrafo seguinte às observações do protagonista sobre as altercações entre os amigos: "Para serenar a roda, propus um novo chope, no que fui aplaudido calorosamente por Florêncio" (ANJOS, 2006, p.16). Os desentendimentos, no entanto, ocorrem mais uma vez:

- Cidade besta, Belo Horizonte! Exclamou Redelvim, consultando o relógio. A gente não tem para onde ir....

- Não acho! retrucou Silviano. Em Paris é a mesma coisa.

- Em Paris? Perguntou Florêncio. Não sabia que você andou por Paris...É boa!

- Ó parvo, quero dizer que o problema é puramente interior, entende? Não está fora de nós, no espaço!

Florêncio, já meio alegre, levou a mão à boca, num riso convulsivo. Redelvim e Glicério 
também desataram a rir. Silviano, indignado, quis retirar-se. Disfarçando o mau epílogo da festa, alvitrei uma retirada em conjunto. (ANJOS, 2006, p.17 - grifos nossos)

Nessa fala de Silviano encontramos o impasse base de todo o romance: o conflito interior é visto, também pelo narrador-protagonista, como sendo motivador das suas aflições, enquanto o espaço físico e as tensões sociais e históricas são apenas acessórios à vida e às suas tribulações.

Apoiado na concepção existencial do amigo conservador, ele tenta seguir a sua vida a partir da conduta católica e da harmonização do mundo. O saudosista de Vila Caraíbas, não goza, no entanto, de uma situação financeira que lhe retire a preocupação econômica. Nos momentos em que as duas irmãs adoecem, por exemplo, os problemas materiais são realçados.

Nem economicamente estável para lidar apenas com os problemas eternos, nem ideologicamente coeso para tratar dos impasses sócio-históricos, Belmiro se encontra no entre-lugar entre o devaneio transcendental - que o leva a idealizar uma relação amorosa e apegar-se a sua juventude, prendendo-se a dois cenários fantasiosos - e o presente material - que requer a defrontação com os contratempos ligados à ordem econômica. 
A evasão desse presente turbulento ocorre no deslocamento dos movimentos psíquicos do protagonista para o seu passado rural. A equação, entre o passado e o presente, é mais ou menos a mesma de Angústia; no entanto, a solução formal/conteudista de Cyro é bastante distinta. Belmiro, muito diferentemente de Luís da Silva - que age -, é um melancólico conformista, tentando contar apenas as suas façanhas em Vila Caraíbas. Entretanto, o presente, que ele tanto afugenta, toma conta do seu diário.

O deslocamento espaciotemporal estabelece, em Belmiro, não apenas um choque temporal - entre os valores, por exemplo, das mulheres Vila Caraíbas e os das de Belo Horizonte, entre o ritmo de um lugar e de outro, entre o "adolescente que permanece no adulto" (ANJOS, 2006, p.36) - mas, sim, um conflito entre idealização - fonte de evasão da realidade - e a realidade em si.

Como Fernando Gil (1999, p.126) afirma, Belmiro está inserido entre duas concepções sociais antagônicas: "de um lado, uma experiência referenciada pela experiência tradicional rural e tradicional, de outro, pela experiência moderna, urbana e burguesa." A dialética da cidade presente e do campo reminiscente, nesse caso, engendra um sentimento de desconexão com o agora, que ele abranda tão 
somente na sublimação do passado. A fim de ser apto a viver o presente descompassado valorativamente, há de se fazer um esforço rememorativo. Como diz Antonio Candido (1992, p.81):

O drama é o presente que se insinua no passado. Se fosse possível viver integralmente no mundo recriado pela memória, haveria a possibilidade de um modus vivendi, quase normal, a seu jeito, como o do narrador do Temps perdu. Acontece, porém, que a sensibilidade de Belmiro, jogando-o como uma bola entre o passado e o presente, perturbando este com arquétipos daquele, desmanchando a pureza daquele com intromissão das imagens deste, não lhe permite uma existência atual.

A flutuação temporal do romance, mediada com os conflitos sociais do tempo histórico, é vital no processo de entendimento da visada melancólica de Belmiro sobre o mundo e a alteridade.

\subsection{O DESLOCAMENTO ENTRE O SOCIAL E O RELIGIOSO N'O ANJO, DE JORGE DE LIMA}

Luís Bueno (2015, p.219), ao referir-se à prosa de Jorge de Lima, afirma que acompanhá-la “é andar por terrenos acidentados", em razão do artista alagoano ter sido um de nossos escritores que mais arriscou, "tentando de tudo e investindo toda a sua força artística tanto nos grandes projetos quanto nas obras de circunstância". A ideia de que Jorge de Lima fez uso dos mais diversos expedientes 
narrativos na construção de seus romances é reafirmada por William Cereja (2002, p.113): “Nas obras de ficção de Jorge de Lima, evidencia-se [...] a preocupação de narrar com diferentes enredos uma mesma fábula, a fábula original [...]". Não só diferentes enredos, mas diferentes modos de composição ${ }^{1}$ dessas histórias, marcadas pela cosmovisão católica do autor, que tenta retomar constantemente o mito adâmico.

Entretanto, mesmo que predomine a questão cristã em $O$ anjo - nos embates ditos universalizantes e atemporais entre o bem e o mal, na volta ao tempo mítico, em contraposição ao histórico, por exemplo - a narrativa é implicada em tensões socio-históricas. Os aspectos formais do romance, embora ilhem os momentos tensionais, não conseguem apagá-los totalmente. Quando eles são encontrados, o olhar hermenêutico pode voltar-se para o subtexto social.

Cereja (2002, p.98) destaca que $O$ anjo

herda fortes influências do experimentalismo brasileiro dos anos 20, inclusive com nítida intenção surrealista, ao mesmo tempo que apresenta certos aspectos constitutivos da prosa de ficção da década de 30 , como o regionalismo e as preocupações de ordem espiritual e religiosa.

1 Muito diferentemente de $O$ anjo, Calunga, por exemplo, representa o fracasso de Lula, protagonista da narrativa, em tons parecidos com os do romance social em moda na época. 
Diante de tal síntese, a narrativa parece condensar as tendências do romance de 30, dispondo, concomitantemente, da verve social (como o regionalismo da época era visto) e da intimista (como a religiosidade na literatura da época era vista). Tentemos realçar, por aqui, a forma social dessa narrativa, por meio dos deslocamentos espaciotemporais nela figurados.

Todo o primeiro capítulo do romance é dedicado ao ato reminiscente que apresenta Herói quando menino, adolescente e adulto, num breve panorama de formação do homem; no começo do segundo capítulo, o protagonista encontra-se no presente da narração. O narrador introduz, já nessas primeiras páginas, a figura do Anjo; antes disso, no entanto, temos a representação edênica da sua casa e do seu seio familiar:

Na memória de Herói um dos espetáculos mais vivos da meninice era a sala de jantar onde desenhava aos seis ou sete anos.

Ilha Grande. Sala de casa colonial no Norte. Um candeeiro imponente. O menino rabiscava, rabiscava, 8, 9, 10 horas da noite.

As sombras familiares projetavam-se na parede. Mamãe. A irmã. Os outros irmãos menores lendo, colorindo cadernos. As outras irmãs tão brancas, tão puras, tão serenas, costurando. Tio Agnelo tocando violocenlo. (LIMA, 1998, p.11) 
A visão do menino dá conta da grandiosidade do lugar, pintando a harmonia instaurada na família por meio da descrição dos afazeres e dos estados de espírito das pessoas que o rodeiam. Repentinamente, porém, a rememoração passa a relatar a adolescência da personagem principal; é nela que, depois da repreensão dos pais após ele clamar, no colégio, pela liberdade absoluta do suicídio, Herói pede a Deus um anjo da guarda. O seu pedido é concedido, encontrando o Anjo no começo de sua vida adulta, acompanhando-o durante os seus percalços.

No segundo capítulo, a rememoração é cortada, direcionando a narrativa para o apartamento no Rio de Janeiro em que o Herói e o Anjo vivem. É composta, assim, a primeira mudança espaciotemporal do romance, que, no primeiro momento, não parece significar muito em termos de choques de princípios, uma vez que o pintor - Herói - e o seu guardião estavam instalados numa ampla moradia, ocultos do caos da então capital brasileira. Contudo, posteriormente ao fracasso de uma exposição do protagonista, gerando uma crise financeira, eles decidem passar a morar no ateliê de Herói, localizado no "13으 andar do Cinedifício" (LIMA, 1998, p.22).

A mudança acarreta uma maior proximidade das duas personagens com o espaço da cidade que as circunda, 
representando uma tomada de consciência no que tange aos desdobramentos da urbanização carioca, a partir da reiterada focalização do Herói sobre o mundo:

Herói se lembra da medalhinha com os olhos de Santa Luzia, no pescoço, quando pequenino, que sofreu da vista.

Porém sons de sino lá [no ateliê] nunca aportavam. Nem de órgãos, nem de coisas de Deus. Só motores de avião em cima, buzinas de ônibus, de autos, embaixo. Todas as presepadas do progresso com que o Homem se inquieta de aflição. (LIMA, 1998, p.22)

Em contraposição aos tempos de menino, quando reinavam a pureza e a harmonia, ouvindo-se os acordes do violoncelo, a cidade propaga o barulho e a desordem ocasionados pelo progresso. Toda aquela turbulência causava a confusão de diversos valores: "No ar vozes, cantos se cruzavam por via dos rádios. E até aquela altura se captavam safadezas de cabarés, coros de primeira comunhão, vozes de frades alternativamente" (LIMA, 1998, p.22). Interpolam-se, então, sons sacros e ruídos pecaminosos, estabelecendo o ponto de inflexão da narrativa, que começa a tratar da queda de Herói correlacionada à perversidade atraente do espaço circundante.

Na página seguinte, o narrador, por meio dos olhos do Herói, continua maldizendo o progresso, realçando a desumanidade contida na mecanização do trabalho: 
De junto do edifício de seu ateliê se construía o Teatro Mix.

Herói assistira àquele mundo nascer. Nos primeiros dias foram engajados magotes de trabalhadores para alisar terreno, desbravar, limpar o solo em que há poucos anos as freiras do convento da Ajuda se moviam lentamente no interior de âmbitos de cela.

Passados os primeiros dias despediram quase todo aquele enxame de braços desesperados de pão e trabalho, porque instalaram ali a máquina automática de cavar e de plantar estacas, a serviço do grande capital. [...] 0 grande bicho comeu o pão daqueles homens. (LIMA, 1998, p.24)

A narrativa, nesse momento, modula-se em tons de crítica social, ou melhor, de crítica social fincada numa cosmovisão católica permeada pela insatisfação diante do status, do protagonista, na cidade. O deslocamento de Herói não cria, necessariamente, uma crise identitária; o seu colapso moral irrompe quando ele não mais pode se esconder das tentações do meio. Sempre fragilizado, o protagonista necessita de proteção irrestrita e de conforto financeiro: da família quando menino no campo e do Anjo quando adulto e como pintor de sucesso. Fracassada a profissão, a Queda ocorre.

Da página 27 à 36, da nossa edição, são contadas as aventuras pecaminosas de Herói, bebendo e apostando na então capital 
brasileira. Na página 37 o protagonista volta para a fazenda da Ilha Grande, onde é recepcionado calorosamente pela família. O retorno à terra natal, entretanto, requere mais uma adequação de Herói, que lá sente-se indisposto e melancólico, pois:

Sua memória não tinha mais braços abertos para o ambiente de sua meninice. Procurou as sombras que $o$ antigo candeeiro fazia tremer nas paredes. Agora a lâmpada elétrica iluminava tudo diferente. Mão-preta já não existia. Tio Agnelo morrera. Cidade e serras, uma ova! (LIMA, 1998, p.40)

Retomando as primeiras linhas do romance, o narrador confronta os sentimentos saudosistas de outrora com os desapaixonados de agora. Não é apenas a instalação da luz elétrica - a modernização do campo - a causadora da acídia, mas o tempo decorrido que vitimara os seus queridos; isto é, a crise espaciotemporal está estritamente ligada ao conflito da ordem dos afetos. Essa desorientação é intensificada pela abstemia do Herói, que se tornou dependente de bebidas alcóolicas durante a sua Queda moral no Rio de Janeiro. O Anjo, pacientemente, consegue curar o protagonista, diminuindoIhe a administração de cachaça. A disforia desaparece do Herói, que procura reaproximar-se carinhosamente do local de sua infância. 
O gosto pela terra é reavivado demasiadamente. Herói, passeando pelos arredores da fazenda, ao observar os meninos pobres tirando sururu, lembra dos infortúnios daquele território, como a geofagia e a maleita. O exame dessas mazelas, ao invés de produzir novo corte disfórico na narrativa, é tratado positivamente: “Tudo é bom. A miséria é boa. A lama é amorosa. Parece que a vida é uma feitiçaria de sonho de maleita" (LIMA, 1998, p.49).

A ruptura do sentido eufórico de Herói efetua-se páginas à frente, motivada, especialmente, pela maleita que o contamina. A sua fraqueza, diante da terra que o traga, leva o Anjo e o administrador da fazenda a aconselharem o retorno do protagonista para a capital:

- Herói, você precisa mudar de clima. Você contraiu sezões aqui, e estes males não acabam no lugar em que se pegou.

Então o administrador da fazendo disse:

- Esta ilha só serve mesmo para esse pessoal acostumado na lama. O doutor já é estrangeiro. (LIMA, 1998, p.54)

Herói situa-se, assim, num entre-lugar crítico irresolúvel: perturbado na capital, adoentado na terra de nascimento e impossibilitado de retornar ao espaço-tempo de sua infância, ele é lançado de um lado para o outro pelas personagens: 
é o irmão que o busca, mandado pelos pais, quando eles enxergam necessidade de sua volta à fazenda, e é o Anjo e o administrador da fazenda, com o assentimento da mãe, que tomam a decisão no que tem a ver com o seu retorno ao Rio de Janeiro.

Mais uma vez na cidade grande, uma nova Queda do Herói é iminente. Desassossegado, ele se aquieta somente quando - Anjo executa músicas que guiam o protagonista em direção à sua infância: "Então vamos para o passado. Vamos para a monarquia. O Anjo tocava valsas daquele tempo sereno. E o ambiente melhorava, num átimo" (LIMA, 1998, p.57).

Contudo, esses momentos não são duradouros. Logo Herói é seduzido por Salomé - que rapidamente o abandona - e reinicia a jogatina de outrora, à procura de dinheiro. O Anjo, desencantado com a trajetória do protagonista e com as suas infrutíferas tentativas de ajudá-lo, retira-se do ateliê. Sozinho, Herói atira-se - numa Queda literal e metafórica - do $13 \%$ andar da Cinelândia. Com o auxílio do Anjo - transferindo o seu sangue para o do protagonista o personagem-principal sobrevive, porém cego e maneta. Essas características, no entanto, impedem-no de atentar contra a própria vida de novo: "Herói repetia: - Jesus me prendeu à força. Jesus me acorrentou" (LIMA, 1998, p.73). 
Em tons de delírio, a narrativa termina com o protagonista proclamando a força divina que o aleijou, possibilitando-o a convivência com a enfermeira do hospital em que ele é atendido:

- Meu Deus, conservai-me cego e sem mãos para que a Bem-Amada sempre exista.

Parecia vir uma voz vertical - lá de baixo, do passado. Voz muito igual à do padre-mestre Anselmo de Ilha Grande:

- A Graça é mais veloz que tudo! (LIMA, 1998, p.75)

Na travessia de Herói - que pode ser vista como o símbolo do trânsito entre o bem e o mal, o limpo e o ímpio, a ascensão e a queda - há um plano social e histórico, senão evidente, pelo menos sub-reptício. A história termina com a volta da visão do passado infantil, dando a entender que a aceleração da modernidade é dominada pela velocidade da Graça Divina. Como diz Ivo Barbieri (2009, p.83):

Indícios do Futurismo repontam na visão tumultuada do progresso materializado na voracidade insaciável do capital, nas máquinas que reduzem conventos a pó e no furor ascensional dos arranha-céus que produzem uma babel dos tempos modernos.

A salvação, então, é rejeitar o progresso a todo custo, num retorno ao tempo mítico; essa narrativa de Jorge de Lima, no entanto, coloca o protagonista em embate com o tempo 
histórico, até datando a formação, no primeiro capítulo, dele como adolescente "1914, 15, 16" (LIMA, 1998, p.12) e como adulto "1917, 18, 19, 20" (LIMA, 1998 p.12). Além disso, os deslocamentos espaciotemporais estão conjugados não apenas com a perda da pureza do mundo, mas, também, com a perda de proteção e de capital do Herói.

Os momentos de Queda moral do protagonista realizamse nos instantes de sua degradação econômica, ambas no Rio de Janeiro: quando se muda para o ateliê, e tem diante de si as marcas indeléveis do desenvolvimento tecnológico na vida do homem, e quando volta da fazenda, com o agravamento de que o Anjo deixa de zelar por ele; na fazenda, os outros o veem como inadequadamente fraco demais para lidar com as intempéries do clima da terra. Enfim, a saída para o Herói não é apenas o retorno às suas origens, mas, sim, o regresso à uma vida harmoniosa, em que ele, "filho do coronel" (LIMA, 1998, p.37), era acolhido no seio familiar.

Finalmente, rever a meninice é reanimar o prestígio que não mais detinha nos momentos de sofrimento na capital. As tensões históricas e sociais, assim, estão intimamente ligadas ao plano da visão de mundo católica, que, tratando do enredo da salvação a partir da inocência do campo e da infância, privilegia esse modus vivendi, e por consequência, 
reverbera, com o foco narrativo no Herói - que, em certo instante, vêa pobreza com regozijo-a ideia de que o equilíbrio vital do mundo encontra-se sob o mando dos poderosos do Nordeste. Os deslocamentos espaciotemporais, nesse caso, são basilares na formulação da história. Sem eles, não haveria tensão na equação entre o imponente arcaico do campo da infância e o progresso perverso da vida adulta do Herói, representados, respectivamente, pela fazenda e pela cidade do Rio de Janeiro.

\section{CONSIDERAÇÕES FINAIS}

Lendo o que Mário de Andrade escreveu em "Elegia de abril", Ivan Marques (2015, p.67) afirma que um dos motivos dos autores do romance de 30 realçarem, conscientemente ou não, a derrocada de suas personagens, é encontrado no afã "pôr a nu as exclusões e rachaduras da organização social, a manutenção do atraso mesmo em contexto marcado por mudanças, numa palavra, o fracasso da modernização brasileira", trazida à tona em todas as narrativas aqui estudadas, seja acarretando tensões internas e/ou externas, porém processadas na dialética do espaço-tempo.

Os deslocamentos acentuam esse sentimento de derrota. Quase todos os estudiosos que revisam o texto em voga de Mário de Andrade evocam Belmiro e Luís da Silva, além de outras personagens, como construções-chave 
dentro da dinâmica do ser-de-papel fracassado. Essas duas personagens, curiosamente, atravessam, mais ou menos, a mesma equação de mudanças espaciais, temporais e valorativas: deixam o campo, onde a família ainda detinha certos poderes, carregando consigo os preceitos de então, para se instalarem em capitais, que requerem deles uma adaptação à nova ordem social. Enquanto Cyro dos Anjos simboliza a inadequação a partir da melancolia e da frustração, Graciliano Ramos evoca o desajuste por meio da mania e da loucura, ambos a partir de processos rememorativos. Os dois, de fato, fracassam: Belmiro termina o seu diário solitário, sem ver mais propósito em levantar lembranças de Vila Caraíbas; Luís da Silva, mesmo matando o catalizador do seu sofrimento, Julião Tavares, não consegue voltar a deter o mesmo poder de sua família, uma vez que o tempo é irretornável.

Em Maleita, de Lúcio Cardoso, também há um jogo valorativo tensional. Nele, no entanto, os embates referem-se mais ao espaço do que ao tempo, uma vez que as divergências são animadas pela mudança de Curvelo para Pirapora. A ânsia de modernização, veiculada pela personagem principal, impacta os costumes dos outros viventes. O progresso, no caso, viria à custa da imposição violenta dos "valores da civilização àqueles homens reduzidos 
a uma vida animal" (BUENO, 2015, p.205). O deslocamento do protagonista, nesse esquema de princípios, cria um sistema de antagonismos truculentos entre uma autoridade opressora e um povo reativo. A dinâmica dessa narrativa, então, evidencia o processo combativo de desacerto entre alteridades. No fim e ao cabo, o protagonista fracassa tanto no empreendimento de modernizar a terra, quanto no de alterar o modo de vida dos outros; ao contrário, ele se aproxima deles através do contágio com a maleita.

Já n'O anjo, a constituição da forma/conteúdo nubla uma hermenêutica pautada na apreensão da tensões histórico-sociais da narrativa. Com capítulos bastante curtos e aparentemente desconexos, o romance é construído por meio de fragmentos de histórias que se juntam num panorama formativo do caráter de Herói e de sua Queda perante os desígnios divinos.

O conservadorismo dos preceitos católicos, colocados em jogo no livro, atuam como ponto antitético no que se relaciona com a modernização carioca; no corruptivo Rio de Janeiro, os vícios do jogo e da bebida, e o contato com a mulher ímpia, são fatais. Dentro dessa visão de mundo, então, há a contraposição aos movimentos histórico-sociais do progresso que, no fim e ao cabo, estão inseridos na lógica capitalista do nosso começo de século XX. Os deslocamentos 
espaciotemporais, entre a fazenda no campo Nordestino e o ateliê no Rio de Janeiro, portanto, conjugam diversas tensões, fomentando a Queda, símbolo do fracasso moral da personagem principal.

Por último, percebeu-se que o deslocamento e a visada negativa sobre o eu e o mundo podem ser atestados tanto em narrativas de formas simbólicas mais ligadas à esquerda, como aquelas à direita do certame político no decênio de 30. Todas, no entanto, trazem à tona, por meio de diferentes edificações, tensões originadas pelas mudanças no espaço e no tempo, sobretudo no contato com a alteridade - trazendo consigo outras visões de mundo - e com os preceitos de lugares e tempos em contraste com aqueles notados na formação das personagens. São requeridas delas, então, a adequação identitária com a região do agora, que, angariada ou não, é vista desfavoravelmente, como um fracasso.

\section{REFERÊNCIAS}

ANDRADE, Mário de (2002). Elegia de abril. In: Aspectos da literatura brasileira. Belo Horizonte: Editora Itatiaia. p.207-220.

ANJOS, Cyro dos (2006). O amanuense Belmiro. 6.ed. São Paulo: Globo. BARBIERI, Ivo (1998). Posfácio: um anjo paradoxal. In: Lima, Jorge de. $O$ anjo. 4.ed. Rio de Janeiro: Civilização Brasileira. p.77-92.

BOSI, Alfredo (2006). História concisa da literatura brasileira. 43.ed. São Paulo: Cultrix.

BUENO, Luís (2015). Uma história do romance de 30. São Paulo: EDUSP/ Campinas: Editora da Unicamp. 
CANDIDO, Antonio (1992). "Estratégia". In: Brigada ligeira $e$ outros estudos. São Paulo: Editora Unesp. p.78-85. (1989). "Literatura e subdesenvolvimento". In: . $A$ educação pela noite e outros ensaios. São Paulo: Editora Ática. p.140-162. (2001). "Prefácio". In: MICELI, Sérgio. Intelectuais à brasileira. São Paulo: Companhia das Letras. p.71-76.

CARDOSO, Lucio (2005). Maleita. Rio de Janeiro: Civilização Brasileira. CEREJA, William (2002). "A queda ou o salto para o alto: o religioso na ficção de Jorge de Lima". Teresa, São Paulo, (3), 97-125.

COUTINHO, Afrânio (1997). A literatura no Brasil: Era Modernista. 4.ed. São Paulo: Global.

CRESSWELL, Tim (2006). On the Move: mobility in the modern western world. Londres: Routledge.

FURTADO, Pedro Barbosa Rudge (2017). Rememoração em Graciliano Ramos: do romance à autobiografia. Dissertação de Mestrado. UNESP, Araraquara.

GIL, F. C. (1999). O romance da urbanização. Porto Alegre: EDIPUC. LIMA, Jorge de (1998). O anjo. 4.ed. Rio de Janeiro: Civilização Brasileira. MARQUES, Ivan (2015). "Herói fracassado: Mário de Andrade e a representação do intelectual no romance de 30". Teresa, São Paulo, (16), 55-74.

MICELI, Sérgio (2001). "Intelectuais e classe dirigente no Brasil (19201945)". In: ______. Intelectuais à brasileira. São Paulo: Companhia das Letras. p.69-281.

RAMOS, Graciliano (2011). Angústia: 75 anos. Rio de Janeiro, São Paulo: Record.

SCHWARZ, Roberto (2008). "Sobre $O$ amanuense Belmiro". In: .0 pai de família e outros estudos. São Paulo: Companhia das Letras, 2008. p.9-21. 
Pedro Barbosa Rudge Furtado é Mestre em Estudos Literários (Unesp/2017) , com a dissertação Rememoração em Graciliano Ramos: do romance à autobiografia. Possuiu financiamento da Capes e está cursando o doutorado na mesma instituição. Especialista em crítica da narrativa e teoria literária. Concentra-se no estudo da Literatura Brasileira, principalmente na prosa do decênio de 30, por meio de investigações da Crítica Dialética. É autor de três artigos, um deles já publicado, versando sobre as figurações do tempo e o efeito de não-pertencimento em personagens de Graciliano Ramos, e dois em prelo, um sobre Caetés, também do escritor alagoano, e o outro sobre Calunga, de Jorge de Lima. Publicou, ainda, trabalhos em anais de congressos. Participa de dois grupos de pesquisa: GEN (Grupo de Estudos da Narrativa) e Diálogos Literários. Lattes: http://buscatextual.cnpq.br/buscatextual/visualizacv. do?metodo=apresentar\&id $=\mathrm{K} 4315832 \mathrm{U} 0$

E-mail: pedro.sonata@gmail.com 